\title{
Research on the Management Mode of Project Archives from the Perspective of Project Management
}

\author{
Ma Yanfei ${ }^{1}$ \\ ${ }^{1}$ M.Eng of School of Civil Engineering and Architecture, Anyang Normal University, Anyang, China \\ Correspondence: Ma Yanfei, School of Civil Engineering and Architecture, Anyang Normal University, Anyang, \\ China. Tel: 1-359-811-4693. E-mail: xifeng1234567@163.com
}

Received: November 27, 2019; Accepted: December 13, 2019; Published: December 24, 2019

The research is financed by the Humanities and Social Science Project of Education Department of Henan (No. 2019-ZZJH-087) .

\begin{abstract}
By analyzing present situation and the characteristics of engineering archives management, analyses the engineering archives management the lack of support for the project management; The possibility of application of engineering files in project management is analyzed emphatically. Finally, combining with the actual situation, the paper gives the construction measures of the project archives management mode from the perspective of project management.
\end{abstract}

Keywords: project management, engineering archives, application

\section{Introduction}

Project management refers to the enterprise engaged in project management, entrusted by the construction unit, carries out the whole process or several stages of management and services for the organization and implementation of the project on behalf of the construction unit according to the contract. Project management in China's construction industry has been implemented for more than 20 years, and has achieved great social significance and economic value. Engineering files are the "recorder" and "driver" of engineering project management, which will play a key role in the smooth development of engineering projects and the orderly and efficient implementation of project management. Therefore, the research of project archives management mode based on the perspective of project management has profound theoretical significance and practical value.

\subsection{Status Quo and Characteristics of Project Archives Management}

The documents, drawings and audio-visual materials with archiving and preservation value formed in the construction project activities are the main source of the project archives, which are the important reference basis for the project management, as well as the important technical support materials for the future construction, reconstruction, expansion and demolition of the project. At present, the characteristics of project archives management can be summarized into the following aspects:

\subsection{Project File Management and Project Management are Out of Line}

Due to the large number of units and personnel involved in the construction industry, and the complexity of project construction procedures, it is quite difficult to integrate project file management into project management. In addition, there are still many construction units and construction units' understanding of project files remains at the level of archiving and preparing for inspection, which leads to the fact that project files are mainly collected and arranged after the project, and the management of files is not integrated into the project management. This phenomenon will greatly affect the play of the inherent value of archives, at the same time, due to the lack of file support for project management, will also lead to project management loopholes, deviation, waste and even errors.

\subsection{Project Archives Management Personnel have High Mobility and Low Overall Professional Quality}

At present, due to the deviation of understanding of project files, many construction units or construction units are unwilling to invest manpower, material and financial resources in project files management. In order to save costs, some enterprises do not have fixed archives management personnel. During the project, they temporarily recruit and borrow relevant personnel from the society or other enterprises as project archives management personnel. 
This will lead to project records management practitioners or business quality uneven; Either one person manages the files of multiple projects at the same time, and due to his limited energy, he is tired of dealing with the work.

\subsection{Archives Management in the Traditional Mode, Information Management is Relatively Scarce}

Due to the wrong understanding of engineering files, coupled with the lack of investment, leading to the current stage of many enterprises engineering files management is still using manual sorting, paper media storage based on the traditional file management mode. This management mode has long been unable to adapt to the requirements of the development of today's information society, and at the same time this management mode has greatly restricted the play of the value of archives, indirectly leading to the lack of project management support for engineering archives.

\subsection{Part of the Project Records are not Objective, Inaccurate, and Even Suspected Fraud}

Due to the instability of file management personnel, the collection and arrangement of project files are mainly carried out after the completion of construction activities, which leads to the fact that the records of project files are often filled afterwards. Due to personnel changes in some engineering links, the parties can no longer be found when sorting out the files afterwards. In order to sort out the files, relevant personnel will make subjective assumptions about the contents of the files. Such meeting makes the content that project archives records is not objective, inaccurate, exist even false suspicion.

\section{Research on the Application of Engineering Files in the Whole Process of Project Management}

Engineering archives are records of construction activities generated in the process of project construction, as well as technical support materials for construction and construction. Engineering files are also an important part of engineering project management. Rational and appropriate use of file materials can drive the smooth progress of project management and is an important carrier of project management implementation. The application of project archives in the whole process of project management can be embodied in the following three aspects:

\subsection{Front-End Control}

In the early stage of the construction of an engineering project, the construction unit may, together with the design unit, the construction unit, the supervision unit, the construction archives management department, the project archives manager and other units and individuals, negotiate the standards and specifications for the collection and sorting of engineering archives, and specify the quantity and quality of engineering archives. From the early stage of the project to timely intervene in the management of files, through the standardization of engineering files, the project construction procedures, standards and quality more scientific and reasonable. At the same time, because the archives manager intervene in the project management in advance, it creates the condition for the next project archives to serve the project management in a timely and effective manner.

\subsection{Process Control}

In the construction phase of the project, to achieve a complete system of project files and timely archiving, it is necessary to establish a sense of responsibility "everyone is a file manager". Because engineering project construction is built during, the department that involves and personnel are numerous, each construction activity is carried out relatively frequently, whether project archives can assure continuity in time on content assure undertake sex, depend on special archives worker alone hard complete a task satisfactorily. This asks construction owner, construction technical personnel, supervise to supervise management personnel to want to have the responsibility of archives manager during construction, according to the requirement standard system in time of collect, sort out, report project archives data. At the same time of finishing the work of collecting and organizing files, the process of construction can be standardized through the scientific and systematic files, and the problems existing in the construction can be timely found through the reported files, which have created conditions for the scientific management of engineering projects.

\subsection{Back-End Control}

After the completion and acceptance of the project, the project files shall be handed over to the relevant construction management department. In the process of project operation, maintenance, reconstruction and expansion, the project files shall be timely reviewed to make the project files as an important technical support for the normal operation of the project. At the same time, we should continue to collect and collate the project project after the use of the archives, as far as possible to achieve the project archives systematic and integrity.

\section{Construction of Project Archives Management Mode from the Perspective of Project Management}

To become an integral part of project management, project archives management must innovate management mode and actively integrate into project management. By reforming the project management system, training or 
introducing the project archives management personnel, establishing and improving the project archives standardization system, promoting the project archives information management and other aspects, the project archives to participate in project management to create favorable conditions.

\subsection{The Reform of Project Management System Makes Archives Management an Important Part of Project Management}

Project archives objectively and faithfully record the whole process of project progress, which is the recorder of project management. At the same time, the project files can regulate the activities of the project, and the project files play a driving role. Project archives is an important carrier and gripper of project management. In order to integrate project archives management into project management and give play to the inherent value of project archives, it is necessary to change the current project management mode. The project file manager should participate in the project as the same as the construction technician, supervisor, quality supervision and testing personnel. At the same time, we should pay attention to the use of archival information on the construction of the front end, the whole process and the back end of tracking management, timely summary of archival data, find problems to solve in a timely manner.

\subsection{Increase Input, Train or Introduce Engineering Archives Professional Management Personnel}

Because the archives manager must directly participate in the project management work, this puts forward the higher request to the practitioner's professional quality. In order to train or introduce project archives management professionals, practitioners should have rich archives management experience and profound engineering background, and be competent for project management. We can train project file managers by "going out" and "inviting in", that is, send excellent file practitioners to domestic enterprises and institutions with advanced management concepts to learn from. Invite famous experts and scholars to give lectures on a regular basis. Efforts should be made to improve the professional qualities of archivists and reserve professional talents for high-level project management.

\subsection{Establish and Improve the Standardization System of Engineering Files}

Because the project archives should be used to drive the project management and guide the construction activities through the project archives, it is required to establish and perfect the project archives standardization system with a high starting point. The establishment and improvement of the standardization system should consider the actual management level of the enterprise and combine with the requirements of the local construction department for project files. Make clear the quantity and quality standard of corresponding project files in each construction activity link, guarantee the continuity of project files in time, guarantee the continuity of project files in content.

\subsection{Promote the Project Archives Information Management}

The traditional file management mode, which collects and collates engineering documents and drawings by hand, has been far from meeting the requirements of the development of today's information society. Simple use of Microsoft Office software, strictly speaking, can not be regarded as information management of archives. Archives information management is to collect and maintain project documents are required to follow the file classification arrangement of construction engineering, the construction of electronic documents and electronic records management requirements, unified data format and standard, the implementation file, drawing file cataloging and retrieval of automation, electronic documents fully automated storage and retrieval, image data. Only the information management of engineering files can make it more convenient to inquire, read and use files, improve the use efficiency of files, and provide necessary intellectual support for engineering project management.

Although project archives should be integrated into project management and become an important part of project management, there are still many difficulties to be overcome, as long as we clearly understand that project archives management is an important carrier and gripper of project management, and innovate the project management mechanism, we can certainly make project archives play the role of project driver. Through the innovation of project archives management mode, record and drive the project management to carry out efficiently and orderly.

\section{References}

Hao, W. (2015). Analysis and research on internal control audit of project management [D]. Tianjin University of Technology, 2015.

He, L. H. (2016). Research on construction project archives management mode based on project management [D]. Shenyang Jianzhu University, 2016.

Jiang, Ch. G. (2015). On the role of construction archive informatization in project management [J]. Intelligence, 2015(26), 275-276. 
Liang, Z. Y. (2019). Research on the collection and transfer of project archives [J]. Engineering Technology Research, 4(3), 145-146.

Liu, T. H. (2017). Significance of project archive management in promoting project quality [J]. China Construction, 2017(12), 88-89.

Liu, Z. G. (2019). Research on integration of project archive work into engineering construction [J]. Office Business, 2019(21), 98-100.

Mei, Y. (2015). Discussion on effective management measures of construction engineering archives [J]. Urban construction archives, 2015(12), 31-32.

Sun Lifu. Ways to innovate water conservancy project archives management under the new situation [J]. Henan Agriculture, 2017(20), 46.

Wang, H. M. (2017). "Inclusion" and "integration" of project archives [J]. China Archives, 2017(11), 62-63.

Yang, T. (2019). Practical analysis on digital management of project completion files [J]. Urban Construction Files, 2019(2), 42-43.

Ye, Z. L. (2017). Research on engineering archive management of enterprise group [D]. Hubei University, 2018.

Zhang, F. X. (2018). Strengthening modern engineering management to build quality engineering platform -trends and countermeasures of expressway archives management in the new era [J]. Archives and construction 2018(6), 81-85.

\section{Copyrights}

Copyright for this article is retained by the author(s), with first publication rights granted to the journal.

This is an open-access article distributed under the terms and conditions of the Creative Commons Attribution license (http://creativecommons.org/licenses/by/4.0/). 